Reprod. Nutr. Dévelop., 1988, 28 (2 B), 387-397.

\title{
How does melatonin control seasonal reproductive cycles ?
}

\author{
J. ARENDT, A. M. SYMONS, J. ENGLISH, A. L. POULTON, I. TOBLER (*)
}

Department of Biochemistry, University of Surrey, Guildford, U.K. and $\left(^{*}\right)$ Institute of Pharmacology, University of Zurich, Switzerland.

Summary. The pineal gland is essential for the perception of photoperiod change in many species. Information about photoperiod length is conveyed through pineal secretion of the methoxyindole melatonin. Melatonin, suitably administered in physiological quantities is equipotent with artificial photoperiod in the induction of photoperiodic responses. Most experimental work suggests that it is the duration of high night time melatonin secretion (positively correlated with the length of the natural or artificial dark phase) which conveys the photoperiodic signal. Continuous release implants induce short day effects in ewes, entirely comparable to daily feeding of melatonin or short photoperiod. A minimum duration of secretion rather than a specific duration is therefore probably critical to short day effects. There appears to be a seasonal variation in sensitivity to short day melatonin effects (induction of early oestrus) which can be shifted to an earlier time of year following one oestrus advance the previous year. Short duration melatonin is read as a long day even secreted with 22 hour periodicity, suggesting a lack of circadian variation in sensitivity to melatonin.

\section{Introduction.}

An essential physiological role of the pineal gland is the transduction of photoperiodic information. Pinealectomy or denervation of the gland in a number of photoperiodic species destroys the ability to perceive daylength change, as measured by a variety of behavioural and physiological parameters, but particularly reproductive function. There is no doubt that both of these procedures abolish the rhythmic production of melatonin. Likewise there is no doubt that photoperiod-dependent reproductive function can be driven by appropriate administration of melatonin in physiological quantities (for reviews see Tamarkin et al., 1985 ; Bittman, 1984 ; Lincoln and Short, 1980 ; Arendt, 1986). Thus melatonin is sufficient to drive the photoperiodic response. Moreover there is evidence from the work of Walker et al., 1987, that selective removal of the melatonin signal, by passive immunisation with anti-melatonin antiserum, is equivalent to pinealectomy or long days on FSH secretion at least in the hamster. Thus melatonin is necessary for induction of a photoperiodic response. 
At present the two most important questions which arise concerning the control of seasonal breeding are 1) what are the important characteristics of the melatonin signal and 2) how is the signal read?

\section{Characteristics of the melatonin signal.}

It is now common ground amongst research groups in this area that the secretion of melatonin in entrained conditions and in all species studied, with the possible exception of pigs, occurs during the dark phase of the day and is positively correlated with the length of darkness (Arendt, 1986, fig. 1) in both natural and artificial light conditions. In addition to this overt relationship, it is possible that there are phase changes in the underlying circadian rhythm of melatonin. Certainly this has been observed in human studies (Broadway et al., 1987) and the phenomenon may be dependent on previous photoperiodic history. Moreover there is now clear evidence that melatonin is secreted episodically from the pineal gland at night (English et al., 1987a ; Cozzi et al., 1987). These more subtle characteristics of the melatonin signal seem unlikely, at present, to be of importance in induction of a given reproductive response for reasons which will be elaborated below.

FIG. 1. - Plasma melatonin at $3 \mathrm{~h}$ intervals in 4-6 ewes sampled at 2 week to 2 month intervals for one year. Mean values are shown, whithout statistics, for clarity. Solid bars indicate number of ewes cycling. From Arendt (1985) with permission.

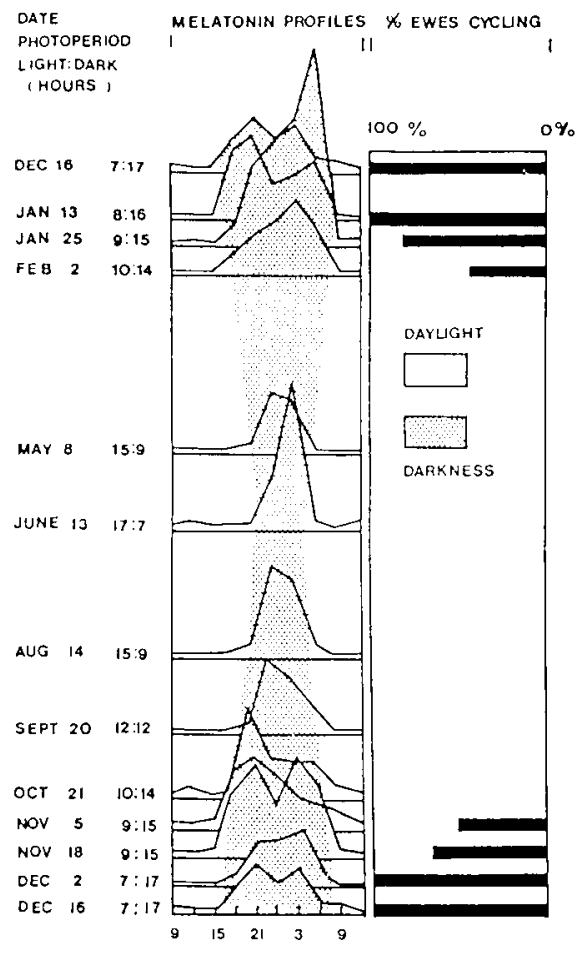


Administration of melatonin either by timed daily feeding, injection (in intact animals), or by infusion (in pinealectomised animals) in such a way as to mimic the length of the secretion profile of a given duration of dark phase, is as potent as the application of the corresponding dark phase itself (in intact animals) in the generation of a reproductive response (Tamarkin et al., 1985). Such exogenous melatonin does not appear in the circulation in an episodic manner, although in the case of daily feeding and injection of melatonin there may be changes in the time of peak melatonin levels in plasma relative to the circadian cycle.

Continuous release melatonin implants of several varieties, for example subcutaneous silastic sachets (English et al., 1986), intra-vaginal sponges (Nowak and Rodway, 1985) and soluble glass intra-ruminal boluses (Poulton et al., 1987b) will induce short day effects at an appropriate time of year in anoestrus ewes whether pinealectornised or intact. Indeed continuous release implants have been used in a variety of species, both peripherally and centrally, for administration of melatonin. There is no evidence to date that such implants provide episodic or even circadian variations in melatonin : simply the continuous presence in plasma or tissue of night time levels of melatonin or above. Hence episodic variations and phase changes in melatonin secretion are probably of little importance in photoperiodic effects.

Rather the hypothesis that the duration of secretion is the critical parameter of the melatonin signal (Carter and Goldman, 1983 ; Bittman, 1984) is supported by the majority of experimental data. In the case of continuous release implants perception of duration of melatonin seems inappropriate. If such treatments are perceived as a short day then a short day melatonin signal must be characterised by a threshold duration of secretion (dependent on photoperiodic history). Beyond this threshold limit the actual duration, up to continuous presence of night time melatonin levels, appears not to be important- although this speculation needs to be substantiated.

\section{How is the melatonin signal read?}

1) Seasonal sensitivity to melatonin implants. - Subsequent to the preceding argument, a melatonin implant administered at any time of the year in natural light should theoretically signal a short day and conversely removal of an implant should signal a long day provided that the requirements of a short day and a long day response are met.

Implantation of melatonin into Suffolk-cross ewes prior to June in natural light at our latitudes $\left(52^{\circ} \mathrm{N}\right)$ was not consistently effective in the induction of early oestrus onset (fig. 2, English et al., 1986). Similar results have been reported by others (Nowak and Rodway, 1985). Thus it is probable that a seasonal variation in sensitivity to melatonin exists. There would appear to be a requirement for a minimum period of long days for a short day response to melatonin implants to be observed. It is possible, however, to shift this seasonal sensitivity to melatonin to an earlier time of year. After an initial advance of oestrus by daily feeding, implantation or artificial short days from mid June, the 
FIG. 2. - Presence of oestrus cycles (solid bars) in 6 groups of 4 Suffolk cross ewes treated as follow: $1 \mathrm{~g}$ melatonin implant from mid-April (IA), mid-May (IM) or mid-June (IJ); fed $3 \mathrm{mg}$ melatonin daily at $16.30 \mathrm{~h}$ from mid-June (MTF) ; kept in 8L : 16D from mid-June (LD) ; kept in natural ligth (C). From English et al., (1986), with permission.

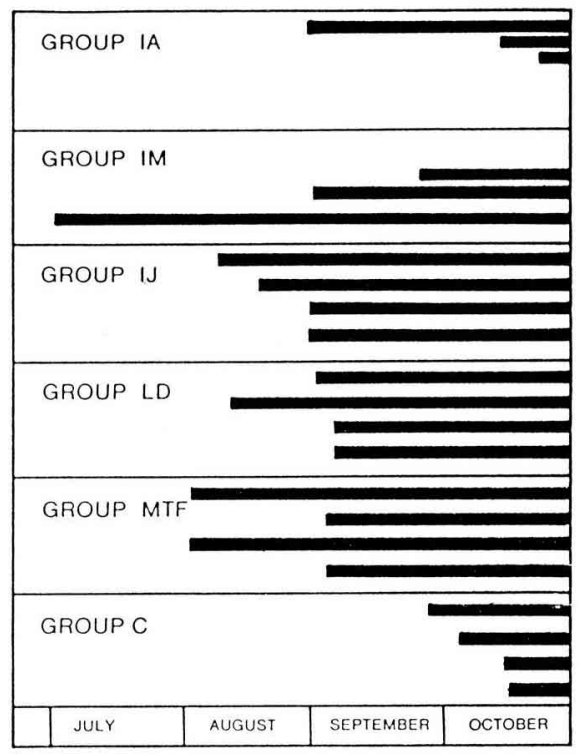

following year all the animals having experienced one oestrus advance were sensitive to melatonin implants the following April. They initiated oestrous cycles in May-June (fig. 3, Symons et al., 1987). This observation has clear practical implications for the control of breeding cycles in field conditions. The mechanism of induction of early sensitivity is a matter for speculation, but at least two possible explanations exist. There may be an endogenous annual rhythm in sensitivity to melatonin which can be rephased by melatonin itself or short day treatment. Alternatively, the arrest of artificial short day or melatonin treatment (which occurred in late November of the first year) might signal a relatively long day. Hence the requirement for long days would be fulfilled prior to implantation in April.

2) Are there differences in the reproductive response to melatonin dependent on the mode of administration? - The oestrus advance induced in Suffolk cross ewes by melatonin implantation, feeding or short days from mid June was indistinguishable between treatments. It is important to note that only very small groups of animals were used in our experiments and that an all-or-nothing response (i.e. onset of ovarian cycles) was observed. It is possible that a graded photoperiodic response such as the plasma level of $\mathrm{LH}$ in ovariectomised, oestradiol implanted ewes described by Karsch and collaborators (Legan et al., $1977)$ or larger numbers of animals might provide a different perspective. On the nther hand we have also followed a number of hormonal parameters in the course of these treatments - prolactin, FSH and LH (pulse frequency, amplitude and mean levels). No melatonin treatment induced any change in LH or FSH prior to the first ovarian cycle (Poulton et al., 1987a). All treatments equally reduced 


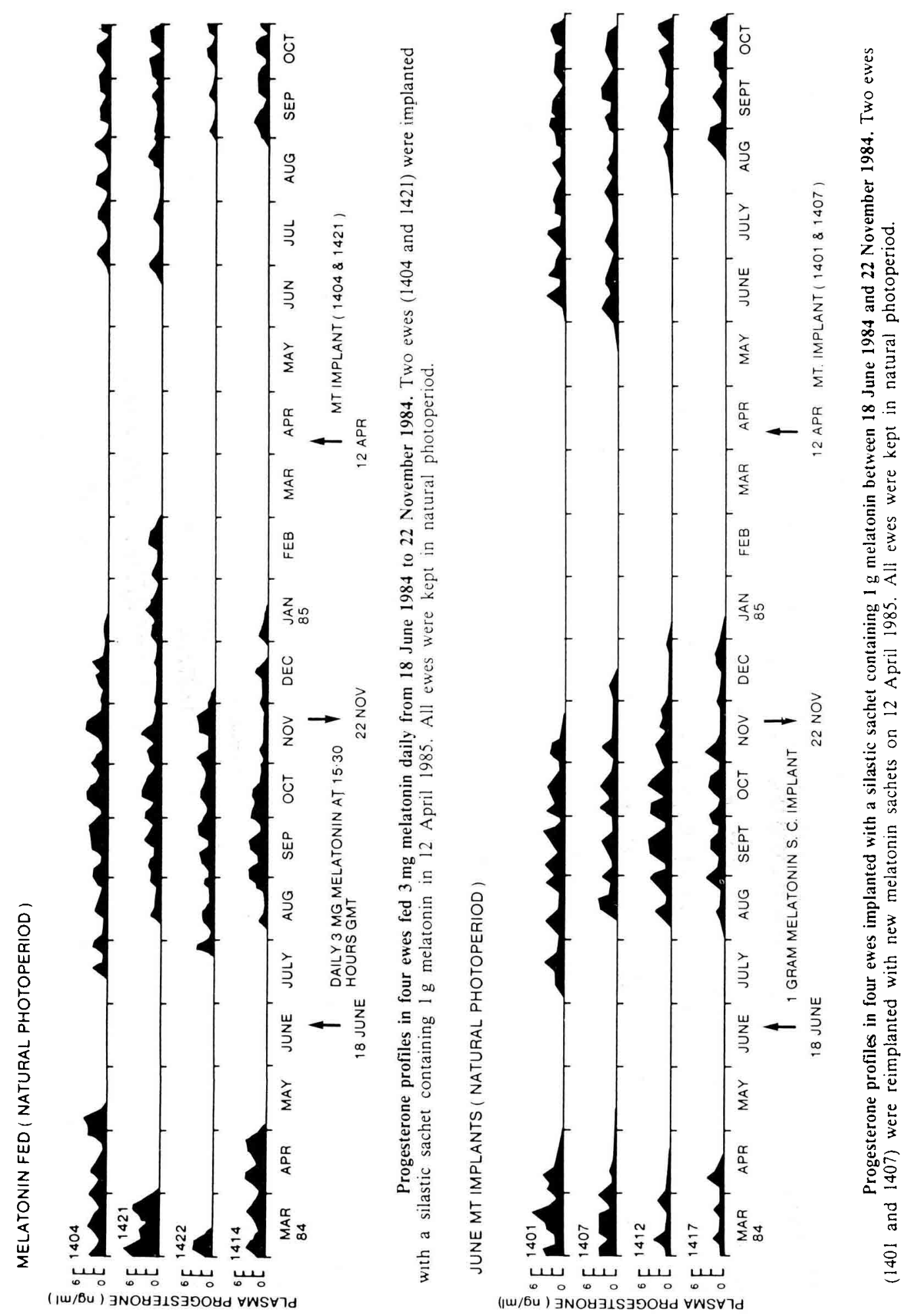



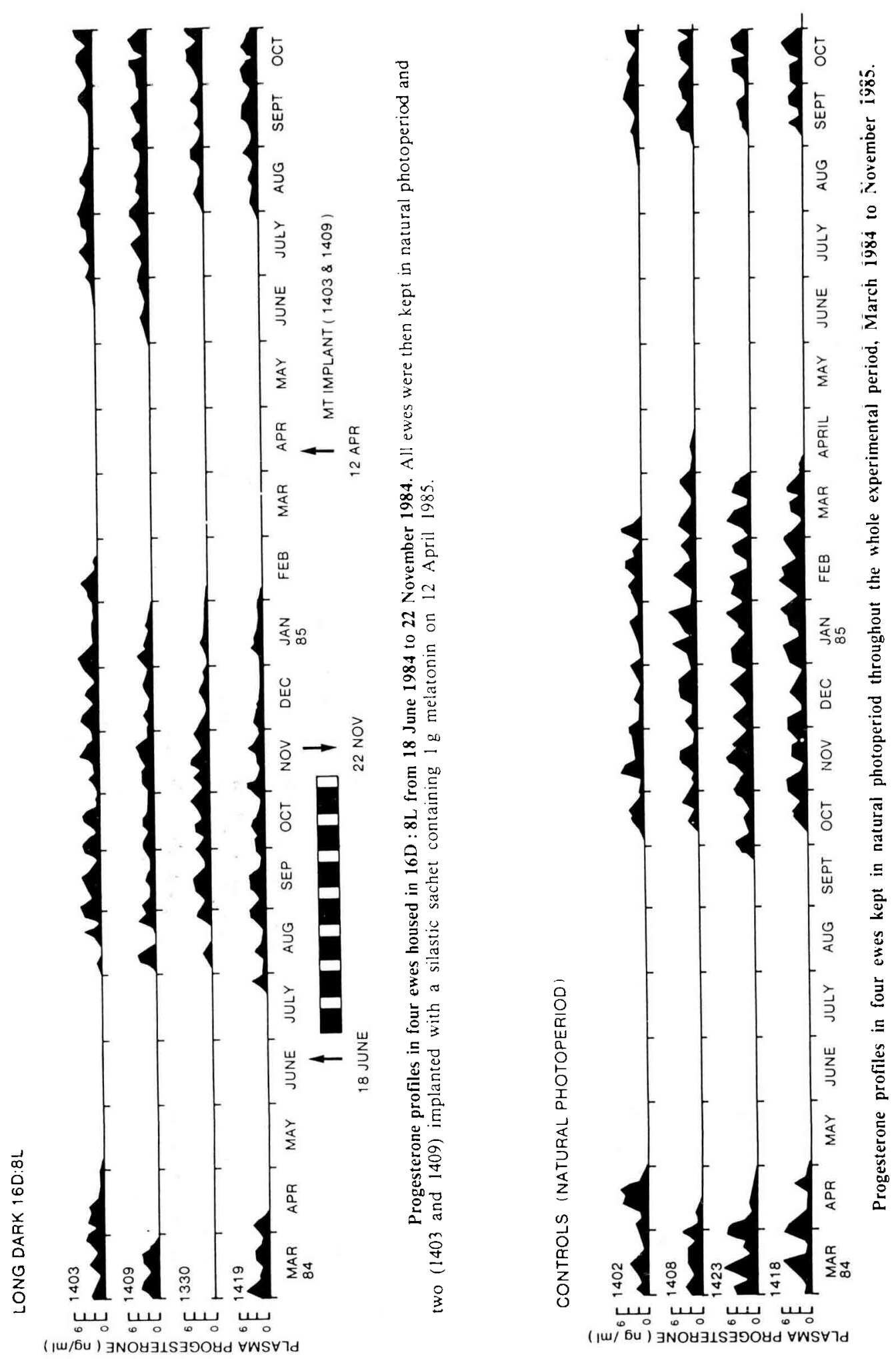
prolactin levels (Poulton et al., 1987a). Once again the treatments were indistinguishable.

If implants do indeed signal a super-short-day, as originally suggested by Lincoln (Lincoln and Ebling, 1985) this should be demonstrable through the induction of a long day response following implant removal and transfer to $\mathrm{e} . \mathrm{g}$. 8L : 16D).

\section{Is the circadian phase position of melatonin secretion important for the induction of photoperiodic effects ?}

Although, as previously stated, the bulk of experimental data suggests that the duration of melatonin secretion is critical for induction of photoperiodic effects, neverthless there is evidence in the hamster for a circadian variation in sensitivity to injected melatonin (Watson-Whitmyre and Stetson, 1983). A number of experiments have been performed infusing melatonin with a given duration and 24 hour periodicity at different times of the light-dark cycle in pinealectomised animals and all have shown that time of day is not important to the response (see e.g. Goldman, 1983 and Karsch et al., 1988). Such experiments do not exclude the possibility of a circadian rhythm in sensitivity to melatonin, entrained by melatonin itself. Moreover the situation in pinealectomised animals may not be equivalent to intacts.

If melatonin can be given with a specific duration and a periodicity which does not entrain a hypothetical circadian sensitivity rhythm, then these two hypotheses might be adequately tested. There is however no marker for such a hypothetical sensitivity rhythm. One approach would be to use a periodicity of melatonin administration outside the range of entrainment - by virtue of the fact that it does not entrain other circadian rhythms. This experiment ideally would be performed in pinealectomised animals using infusion techniques. We have attempted to manipulate the light-dark cycle in such a way as to generate melatonin rhythms with given duration and non-24-hour periodicity in Suffolkcross ewes. We have been able to record activity simultaneously as an index of circadian rhythmicity in some experiments with the help of activity monitors provided by Dr. Irene Tobler and Professor A. Borbely (Institute of Pharmacology, University of Zurich). Only the photoperiodic component of the environment was controlled.

Light-dark cycles of $6 \mathrm{~L}: 16 \mathrm{D}$ are able to entrain melatonin production (fig. 4) with a phase delay of 5-7 h, leading to a shorter duration of secretion ( $9-10 \mathrm{~h}$ ) than sheep maintained in $8 \mathrm{~L}: 16 \mathrm{D}(14 \mathrm{~h})$. The ovarian response to such $22 \mathrm{~h}$ cycles applied from early July is indistinguishable from control animals maintained in natural light, and later than ewes in $8 \mathrm{~L}: 16 \mathrm{D}$, i.e. early oestrus onset is not induced (English et al., 1987b). Oestrus onset was assessed by progesterone levels as previously described (English et al., 1986) and was as follows, days after onset of treatment (July 22nd), natural light : $58 \pm 2 ; 8 \mathrm{~L}: 16 \mathrm{D}: 42 \pm 1$; $6 \mathrm{~L}: 16 \mathrm{D}: 71 \pm 10$ (mean $\pm \mathrm{SEM}, \mathrm{N}=4$ ). 


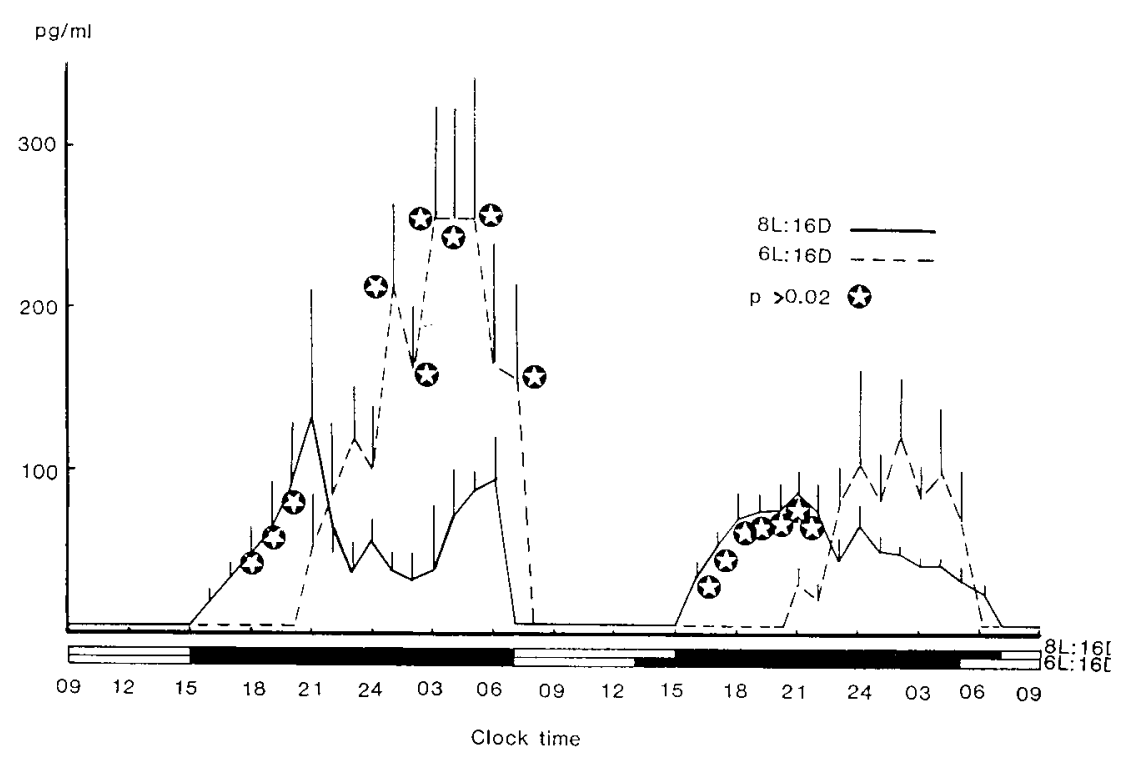

FIG. 4. - Plasma melatonin profiles in ewes maintained for 66 days on short day photoperiods of $8 \mathrm{~L}: 16 \mathrm{D}(24 \mathrm{~h}$ day) and $6 \mathrm{~L}: 16 \mathrm{D}(22 \mathrm{~h}$ day). Each point represents the mean and SEM of 4 ewes. Redrawn from Arendt et al. (1988).

The lack of a short day response in $6 \mathrm{~L}: 16 \mathrm{D}$ could be due to either the shortened duration of secretion, the constantly varying phase position of melatonin or a combination of both effects.

Light dark cycles of $16 \mathrm{~L}: 6 \mathrm{D}$ on the other hand are able to entrain melatonin secretion with no phase delay (fig. 5). In other words animals produce melatonin with a long day duration and $22 \mathrm{~h}$ periodicity (English et al., 1987b). Ewes were maintained from mid-oestrus (December 18th) on 16L:6D and their ovarian function compared with a group on $18 \mathrm{~L}: 6 \mathrm{D}$ and a further group in natural light. Ovarian cycles ceased as follows, days after onset of treatment, natural light : $85 \pm 5 ; 18 \mathrm{~L}: 6 \mathrm{D}, 60 \pm 3 ; 16 \mathrm{~L}: 6 \mathrm{D}, 59 \pm 7$, (mean $\pm \mathrm{SEM}, \mathrm{N}=4$ ). Both 18L : 6D and 16L : 6D groups ceased cycling earlier than natural light controls ( $P<0.05$, analysis of variance and Dunnetts test for least significant difference) suggesting that ewes were able to perceive $16 \mathrm{~L}: 6 \mathrm{D}$ as a long day in spite of the $22 \mathrm{~h}$ periodicity.

Activity recordings were possible in all 4 ewes in $18 \mathrm{~L}: 6 \mathrm{D}$ and 2 of 4 ewes in 16L : 6D for 21 days, beginning 35 days after onset of the treatment. All 18L : 6D ewes showed $24 \mathrm{~h}$ rhythms, albeit very weak in one case. Both 16L : $6 \mathrm{D}$ ewes were arrhythmic. Recordings earlier in 16L : 6D have since shown a fragmentary $24 \mathrm{~h}$ component (entrainment by daily feeding ? masking by feeding ?) but no evidence of $22 \mathrm{~h}$ periodicity. Clearly melatonin was not able to entrain activity rhythms with $22 \mathrm{~h}$ periodicity in these conditions.

Thus the rhythm of melatonin secretion was of long day duration, dissociated from activity rest cycles and produced with a constantly changing phase position 


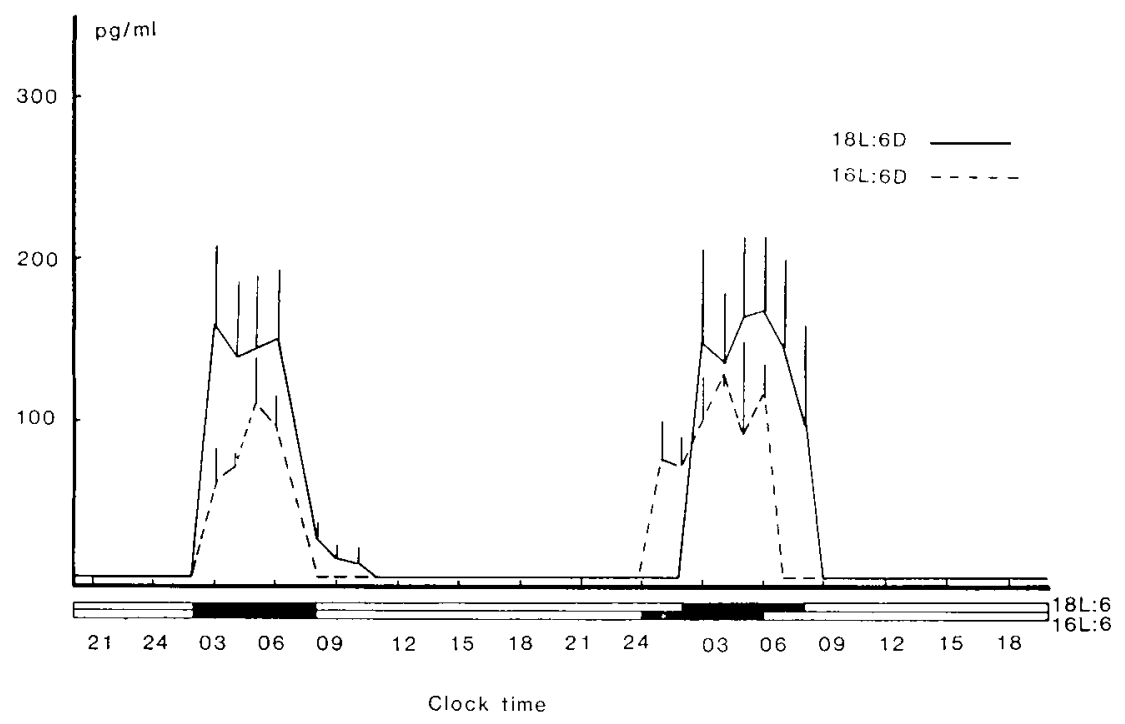

FIG. 5. - Plasma melatonin profiles in ewes maintained for 77 days on long day photoperiod of 18L : $6 D 24 \mathrm{~h}$ day) and $16 \mathrm{~L}: 6 \mathrm{D}(22 \mathrm{~h}$ day). Each point represents the mean and SEM of 4 ewes. Redrawn from Arendt et al. (1988).

with respect to the $24 \mathrm{~h}$ cycle. It was neverthless perceived, at least as far as reproductive function is concerned as a long day.

These experiments serve to reinforce the duration hypothesis as the critical parameter of the melatonin signal, assuming that the hypothetical daily rhythm in sensitivity to melatonin is not entrained by melatonin itself with a $22 \mathrm{~h}$ periodicity.

Colloquium on "Neuroendocrine mechanisms and light control of reproduction in domestic mammals " I.N.R.A., Nouzilly, 17-18 September 1987.

Acknowledgements. - This work was supported by the AFRC.

Résumé. Comment la mélatonine contrôle-t-elle les cycles saisonniers de reproduction?

La glande pinéale est essentielle pour la perception du changement de la photopériode chez beaucoup d'espèces. L'information sur la durée de la photopériode est communiquée à travers la sécrétion de mélatonine par la glande pinéale. La mélatonine, administrée convenablement en doses physiologiques, est équivalente à une photopériode artificielle dans l'induction de réponses photopériodiques. La plupart des travaux expérimentaux suggèrent que c'est la durée de la sécrétion élevée de mélatonine durant la période obscure (corrélée positivement avec la durée de la phase obscure naturelle ou artificielle) qui communique le signal photopériodique. La libération continue par des implants induit un effet de « jours courts » chez la brebis, tout à fait comparable à celui obtenu par un apport 
journalier de mélatonine dans la nourriture ou par des photopériodes courtes. Une durée minimale de sécrétion plutôt que sa durée précise est donc probablement essentielle pour des effets " jours courts ". II semble donc y avoir une variation saisonnière de sensibilité aux effets " jours courts " de la mélatonine (induction du premier oestrus) qui peuvent être avancés à une période plus précoce de l'année à la suite de l'avance d'un oestrus l'année précédente. Une courte durée de sécrétion de mélatonine est lue comme un jour long, même si elle est sécrétée avec une périodicité de $22 \mathrm{~h}$, suggérant un manque de variation circadienne de sensibilité à la mélatonine.

\section{References}

ARENDT J., 1985. Mammalian pineal rhythms. Pineal Res. Rev., 3, 161-213.

ARENDT J., 1986. Role of the pineal gland in seasonal reproductive function in mammals. Oxford Rev. reprod. Biol., 8, 266-320.

BITTMAN E. L., 1984. Melatonin and photoperiodic time measurement : Evidence from rodents and ruminants, 155-192. In The pineal gland, R. J. REITER, Raven Press, New York.

BROADWAY J., ARENDT J., FOLKARD S., 1987. Bright light phase shifts the human melatonin rhythm during the Antarctic winter. Neurosci. Lett. 79, 185-189.

CARTER D. S., GOLDMAN B. D., 1983. Antigonadal effects of timed melatonin infusion in pinealectomised male Djungarian hamster (Phodopus sungorus sungorus) : duration is the critical parameter. Endocrinology, 113, 1261-1267.

COZZI B., RAVAULT J. P., FERRANDI B., REITER R. J., 1988. Melatonin concentration in the cerebral sinuses of sheep and evidence for its episodic release. J. Pineal Res. (in press).

ENGLISH J. E., POULTON A. L., ARENDT J., SYMONS A. M., 1986. A comparison of the efficiency of melatonin treatments in advancing oestrus onset in ewes. J. Reprod. Fert., 7 , 321-327.

ENGLISH J. E., ARENDT J., POULTON A. L., SYMONS A. M., 1987a. Short term variations of plasma melatonin in the ewe. J. Pineal Res., 4, 359-366.

ENGLISH J. E., POULTON A. L., SYMONS A. M., ARENDT J., 1987b. Effects of long and short photoperiod given with $22 \mathrm{~h}$ and $24 \mathrm{~h}$ cyclicity on pineal and ovarian function in the ewe. $\mathrm{IV}$. Coll. Eur. Pineal Study group, Modena, Italy. Abstr. $\mathrm{n}^{\circ} 32$.

ENGLISH J. E., ARENDT J., SYMONS A. M., POULTON A. L., TOBLER I., 1988. Pineal and ovarian response to 22 and $24 \mathrm{~h}$ days in the ewe. Biol. Reprod. (in press).

GOLDMAN B. D., 1983. The physiology of melatonin in mammals. Pineal Res. Rev., 1, 145-182.

KARSCH F. J., MALPAUX B., WAYNE N. L., ROBINSON J. A., 1988. Characteristics of the melatonin signal that provide the photoperiodic code for timing seasonal reproduction in the ewe. Reprod. Nutr. Dévelop., 28, 459-472.

LEGAN S. J., KARSCH F. J., FOSTER D. L., 1977. The endocrine control of seasonal reproductive function in the ewe: a marked change in response to the negative feedback action of estradiol on luteinising hormone secretion. Endocrinology, 101, 818-824.

LINCOLN G. A., SHORT R. V., 1980. Seasonal breeding : Nature's contraceptive. Rec. Prog. Horm. Res., 36, 1-52.

LINCOLN G. A., EBLING F. J. P., 1985. Effect of constant release implants of melatonin on seasonal cycles in reproduction, prolactin secretion and moulting in rams. J. Reprod. Fert., 73, 241253.

NOWAK R., RODWAY R. G., 1985. Effect of intravaginal implants of melatonin on the onset of ovarian activity in adult and prepubertal ewes. J. Reprod. Fert., 74, 287-293.

POULTON A. L., ENGLISH J., SYMONS A. M., ARENDT J., 1987a. Changes in plasma concentrations of $\mathrm{LH}, \mathrm{FSH}$ and prolactin in ewes receiving melatonin and short photoperiod treatments to induce early onset of breeding activity. J. Endocr., 112, 103-111.

POULTON A. L., SYMONS A. M., KELLY M. I., ARENDT J., 1987b. Intraruminal soluble glass boluses containing melatonin can induce early onset of ovarian activity in ewes. J. Reprod. Fert., 80, 235-239. 
SYMONS A. M., ARENDT J., POULTON A. L., ENGLISH J., 1987. Induction of early seasonal sensitivity to melatonin in Suffolk cross ewes. Chronobiol. Int., 4, 219-223.

TAMARKIN L., BAIRD C. J., ALMEIDA O. F. X., 1985. Melatonin : a coordinating signal for mammalian reproduction? Science, 227, 714-720.

WALKER A. P., HASTINGS M. H., BONNEFOND C., ARENDT J. and HERBERT J., 1987. Central passive immunisation against melatonin mimics the effect of lond days or pinealectomy on gonadotrophin secretion in photoinhibited Syrian hamsters. IV. Coll. Eur. Pineal Study Group, Modena, Italy, Abstr. $n^{\circ} 36$.

WATSON-WHITMYRE M., STETSON M. H., 1983. Simulation of peak melatonin release restores sensitivity to evening melatonin injection in pinealectomised hamsters. Endocrinology, 112. 763-765. 